\title{
Gully erosion risk in Hungary
}

\author{
Á. Kertész, G. Jakab \& A. Örsi \\ Geographical Institute, Research Centre for Astronomy and \\ Earth Sciences, Hungarian Academy of Sciences, Hungary
}

\begin{abstract}
In Hungary more than one-third of agricultural land is affected by water erosion; $16 \%$ by wind erosion. The role of gully erosion has been recognized only lately. The main factor of gully erosion risk is soil parent material, i.e. unconsolidated sediments, mainly loess covering two thirds of the country area. The objective of the paper is to review the environmental factors of gully erosion risk based on a country-wide survey and cadastre of the areas endangered by gully erosion. Five pilot areas were selected to study the effects of various environmental conditions in detail. The results include statements on the possible natural and anthropogenic causes of gully initiation and development and risk assessments for the future. The main conclusion is that land use planning should ensure a minimum risk of gully erosion with special emphasis on afforestation.

Keywords: gully erosion, analysis of spatial data, map analysis, land use.
\end{abstract}

\section{Introduction}

Soil erosion is a major problem on hill slopes and in mountains. At first soil erosion research concentrated on sheet erosion. From the 1980s it became evident that the eroding, transporting and relief forming effect of gully erosion may be much more important than that of sheet erosion (Prosser and Abernethy [1], Vandekerckhove et al. [2], Gyssels et al. [3], Nachtergaele et al. [4], Vandekerckhove et al. [5]). That was well known in arid and semi-arid areas whilst in humid and sub-humid regions the important role of gully erosion has only been recognized recently (Poesen et al. [6]). There are contradictory views about the share of gully erosion in the total amount of soil loss in a catchment. Our experiences show that gully erosion processes have a bigger share than those of sheet erosion (Jakab [7]). Gully erosion plays a crucial role in the 
redistribution of eroded soil on a slope and in delivering it to watercourses (Poesen et al. [8]).

The first objective of this paper is to present the results of a countrywide survey to identify the areas where gully erosion is already a major problem. The second aim is a detailed analysis of gully erosion processes in five pilot areas to reveal the main driving forces of gully erosion. Those two approaches provide a good basis to prevent gully erosion in the areas with various degrees of risk. The expected results have not only theoretical, but also practical relevance to enable an expert to plan protecting measures against gullying.

After a short review of soil erosion processes in Hungary, environmental conditions of gully erosion will be presented followed by the applied methods and obtained results of the countrywide survey and the selected pilot areas.

\section{Soil erosion in Hungary}

$25 \%$ of the area of Hungary, 35\% of agricultural land is affected by water erosion (Stefanovits and Várallyay [9], see table 1).

Table 1: $\quad$ Soil erosion in Hungary (Stefanovits and Várallyay [9]).

\begin{tabular}{|c|c|c|c|c|}
\hline & $\begin{array}{c}\text { Thousand } \\
\text { hectares }\end{array}$ & $\begin{array}{c}\% \text { of the total } \\
\text { area }\end{array}$ & $\begin{array}{c}\% \text { of the } \\
\text { agricultural } \\
\text { land }\end{array}$ & $\begin{array}{c}\% \text { of the } \\
\text { eroded land }\end{array}$ \\
\hline $\begin{array}{c}\text { Area of the } \\
\text { country }\end{array}$ & 9303 & 100 & - & - \\
\hline $\begin{array}{c}\text { Area of } \\
\text { agricultural land }\end{array}$ & 6484 & 69.7 & 100 & - \\
\hline Arable land & 4713 & 50.7 & 73.0 & - \\
\hline Total eroded land & 2297 & 24.7 & 35.3 & 100 \\
\hline strongly & 554 & 6.0 & 8.5 & 24.1 \\
\hline moderately & 885 & 9.5 & 13.6 & 38.5 \\
\hline weakly & 852 & 9.2 & 13.2 & 37.4 \\
\hline
\end{tabular}

The significance of soil erosion processes was recognized half a century ago and a soil erosion map was constructed by Stefanovits and Duck [10]. Only the areas affected by sheet erosion are presented on the map and the areas of gully erosion are not shown on it.

\subsection{Water erosion}

\subsubsection{Sheet erosion}

Sheet erosion is an important problem on arable land. Most of the crop is harvested by June leaving large surfaces without vegetation cover during the most sensitive period, i.e. between July-October. Sheet erosion processes are supported by micro-solifluction and by splash erosion (Kerényi [11]). 


\subsubsection{Gully erosion}

Hungarian research recognised the significance of gully erosion in the middle of the last century. The formation and the development of deep-cut tracks were investigated first (Kertész [12]). The role of piping was recognized by several authors (Kerényi and Kocsisné Hodosi [13]). A gully erosion survey was carried out to characterise gully erosion according to the length of gullies in a given area (Stefanovits and Várallyay [9]).

Investigations in Lake Balaton catchment by various authors included also some aspects of gully development (Jakab [7], Tóth and Szalai [14], Jakab et al. [15] and Gábris et al. [16]) investigated the role of deforestation in gully initiation in the nineteenth century.

\subsection{Wind erosion}

$16 \%$ of Hungary's surface is affected by wind erosion. Areas of windblown sand occupy about $20 \%$ of the country's territory. The thickness of the sand varies from a few centimetres to $25-30$ meters. Damage is primarily caused on sandy soils where crop yields may be reduced by up to $50 \%$.

\section{Environmental factors of gully development}

Loess and loess-like deposits cover two thirds of the country's area. Soil erosion is the greatest environmental hazard on hill slopes under cultivation. Other loose sediments like Pannonian sands are also susceptible to gully erosion.

The amplitude and frequency of rainfall events are the most important rainfall characteristics from the aspect of gully erosion. Any change in rainfall regime (e.g. because of climate change) will lead to changes in gully development.

The relationship between land use and gully development is well known. Deforestation and starting agricultural activity on former forested areas increase gully erosion risk also in Hungary.

\section{Methods}

For the country-wide cadastre gullies were digitized from 1:10 000 topographic maps of the Unified National Map System (EOTR), together with land use and soil properties. The Arc Map program (Spatial Analyst/Line density) was used to prepare the gully density map (figure 1), a raster map consisting of $0.25 \mathrm{~km}^{2}$ pixels. Gully density values given in $\mathrm{km} \mathrm{km}^{-2}$ were classified into five categories.

The pilot areas were selected according to the following criteria. Changes of gully development between 1968 and 2004 were studied in the Tetves catchment to study temporal changes. Gully erosion processes in a forested area are shown in the Börzsöny micro-region. The Zselic micro-region is a typical hilly country covered by loess to present gully development on loess. The highest risk of gully erosion is presented in the pilot areas of Medves Hills and Upper-Tarna Hills.

The digital map of the gullies, the map of soil properties, the land use map and the topographic map of the pilot areas were stored in a GIS. The map of soil 


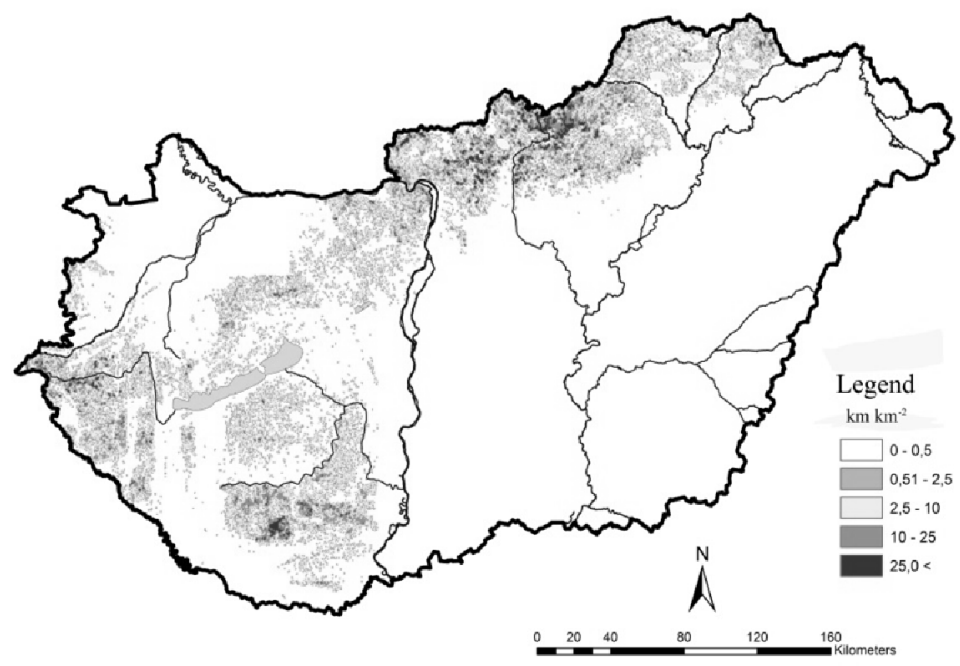

Figure 1: Distribution of gullies in Hungary.

properties is a map series derived from the AGROTOPO map (1:100.000, Rissac [17]). The land use map was compiled on the basis of the CORINE Land Cover database (1:50.000, Büttner et al. [18]). Gully sections with permanent water flow were excluded. Land use types were generalized into six categories (artificial surface, cultivated area, forest, meadow and pasture, wetland, scrub).

Elevation data are taken from SRTM (Shuttle Radar Topography Mission, Rabus et al. [19]). The resolution is $90 \mathrm{~m}$. The soil gradient map with five soil gradient category classes was derived from the elevation model. Soil, land use and topographical data are given for each gully. If a gully extends over two or more pixels then the gully is identified with the value/property occupying the largest area in the gully.

\section{Description of pilot areas}

\subsection{Tetves catchment}

The catchment $\left(120 \mathrm{~km}^{2}, 105-330 \mathrm{~m}\right.$ a.s.1.) is a subcatchment of Lake Balaton (figure 2). Changes of temporal gully development were studied in that pilot area. The results are not presented here (see Jakab et al. [15]).

\subsection{Börzsöny Mountains}

The Börzsöny Mountains (447 km², 120-939 m a.s.1., figure 2) consist of volcanic rocks. The relative relief values gradually decrease towards the borders of the mountain, from $350-370 \mathrm{~m} \mathrm{~km}^{-2}$ to $100-150 \mathrm{~m} \mathrm{~km}^{-2}$ (Madarász et al. [20]). The average annual precipitation is $600-800 \mathrm{~mm}$ (Dövényi [21]). 


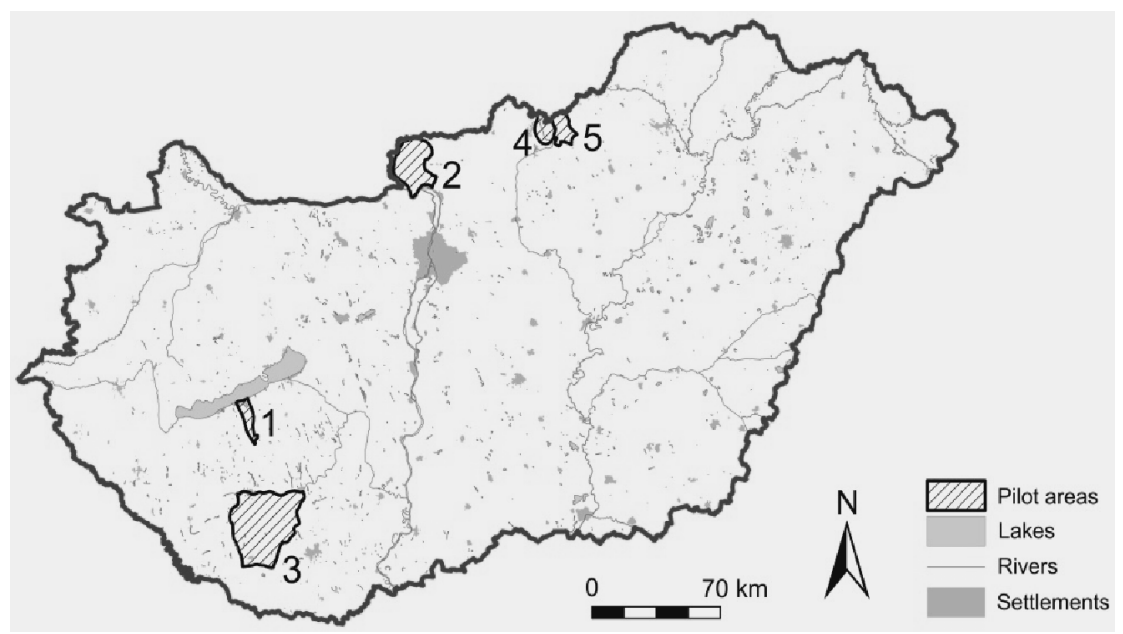

Figure 2: $\quad$ Pilot areas.

\subsection{Zselic Hills}

The relatively flat area of Zselic Hills $\left(1170 \mathrm{~km}^{2}, 200-358 \mathrm{~m}\right.$ a.s.1.) is situated in the southern part of the Transdanubian Hills (figure 2). Almost the whole area is covered by loess. The average relative relief value is $82 \mathrm{~m} \mathrm{~km}^{-2}$. The amount of yearly precipitation is $700-750 \mathrm{~mm}$. In the second half of the last century soil erosion became a serious problem because of the expansion of arable land.

\subsection{Medves Hills}

The Medves Hills micro-region $\left(113 \mathrm{~km}^{2},(200-638 \mathrm{~m}\right.$ a.s.l., figure 2$)$ is located North of Budapest. The value of average relative relief is $118 \mathrm{~m} \mathrm{~km}^{-2}$. Basalt, marl and clay are the main bedrocks in the northern part, clay-sand formations and rhyolite tuff are the bedrocks in the south. The southern part receives 590$620 \mathrm{~mm}$, the northern part $620-650 \mathrm{~mm}$ annual precipitation.

\subsection{Upper Tarna Hills}

The Upper Tarna Hills (118 km², 187-520 m a.s.1., figure 2) are highly dissected, the value of average relative relief is $100 \mathrm{~m} \mathrm{~km}^{-2}$ ). Sandstone, basalt, slope loess and debris loess are the main bedrock types. The mean yearly precipitation is 560-610 mm.

\section{Results}

\subsection{Distribution of gullies in Hungary}

The gully density map of Hungary (figure 1) shows clearly that hilly and mountainous areas are all endangered by gully erosion. The percentage of the 
most affected areas, i.e. that of the upper two categories $\left(>10 \mathrm{~km} \mathrm{~km}^{-2}\right)$ is $5 \%$ (table 2).

Comparing land use, slope gradient and dissection (gully density) maps, the following relationships can be revealed. The highest gully density (the upper two density categories) is in the forested area. The explanation for that is rather simple (see also the Börzsöny pilot area), i.e. gullies and rills will be leveled on arable land and if they are there for a short time, they may not be surveyed and shown on the 1:10 000 topographic maps of. Gullies in the forest are covered by vegetation and they are more or less permanent forms presented on the map. Gullies in the forest may have developed on arable land which was then reforested to stop catastrophic gully incision.

Table 2: Gully density in Hungary.

\begin{tabular}{|c|c|c|}
\hline $\begin{array}{c}\text { Gully density } \\
\mathrm{km} \mathrm{km}^{-2}\end{array}$ & $\begin{array}{c}\text { Area } \\
\mathrm{km}^{2}\end{array}$ & $\begin{array}{c}\text { Percentage of } \\
\text { country area } \\
\%\end{array}$ \\
\hline $0-0.5$ & 75359 & 81 \\
\hline $0.5-2.5$ & 5625 & 6 \\
\hline $2.5-10$ & 7539 & 8 \\
\hline $10-25$ & 3314 & 4 \\
\hline $25-$ & 644 & 1 \\
\hline
\end{tabular}

Looking at the relationship between slope gradient and gully density, it can be established that the highest gully density values are not on the steepest slopes. The central regions of the mountains have very steep slopes but as they have been covered by forest for thousands of years, no gully initiation was possible here. At the fringe of the mountains and in piedmont areas there are many gullies. The most endangered areas are the basins and hilly countries in the northernmost part of Hungary as well as the hilly areas West of the Danube (see figure 1). The most endangered micro-regions are the Upper Tarna Hills and the Medves Hills which will be presented in more detail below.

\subsection{Pilot areas}

The results include statements about the relationship between environmental conditions and the distributions of gully systems. Gully properties are summarized in table 3 . The gully dissection index value is almost the same in the first two pilot areas. Medves and Upper Tarna Hills are two-three times more dissected.

Average gully length is the highest in the Börzsöny and the lowest in the Upper Tarna micro-region. Differences between the average and median values point to the non normal distribution of the data like in the case of the Tetves catchment (Jakab et al. [15]). The differences between the median values are also very small. The minimum gully length values do not refer to real gully lengths as 
Table 3: $\quad$ Main gully properties.

\begin{tabular}{|l|c|c|c|c|}
\hline & Börzsöny & Zselic & $\begin{array}{c}\text { Medves } \\
\text { Hills }\end{array}$ & $\begin{array}{c}\text { Upper } \\
\text { Tarna } \\
\text { Hills }\end{array}$ \\
\hline Number of gullies & 2260 & 6579 & 1979 & 3105 \\
\hline Dissection index (km km $\left.{ }^{-2}\right)$ & 1.43 & 1.45 & 3.595 & 4.355 \\
\hline Total length (m) & 638309 & 1693374 & 464769 & 624948 \\
\hline Average length (m) & 282 & 258 & 243 & 201 \\
\hline Minimum length (m) & 2 & 2 & 12 & 1 \\
\hline Maximum length (m) & 7308 & 16220 & 6996 & 6218 \\
\hline Median (m) & 126 & 133 & 79 & 81 \\
\hline
\end{tabular}

they represent only parts of gullies which are longer but they are cut by the border of the natural micro regions.

Comparing maximum gully lengths of the pilot areas the value of Zselic is more than two times larger $(16 \mathrm{~km})$ than those of the other pilot areas. The explanation is the porous parent material and smaller gradient values in the Zselic area.

There are both differences and similarities in slope gradient distribution of the pilot areas (figure 3). The highest frequency values are in the $5-12 \%$ steepness class except in the Zselic Hills where the first category has the highest frequency. The $0-5 \%$ and $5-12 \%$ slopes are often used for arable cultivation. Arable land without vegetation cover offers ideal conditions for rill and gully initiation as mentioned above. Rills will be removed, levelled by cultivation but deep gullies remain; they cannot be removed by cultivation and the consequence is that they

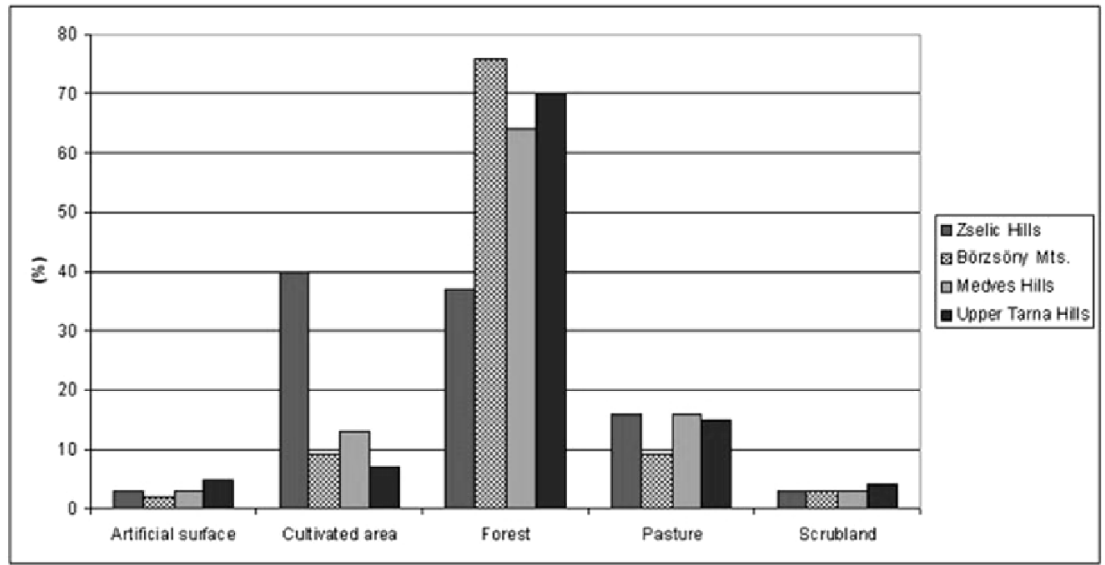

Figure 3: $\quad$ Slope gradient distribution of the pilot areas. 
will soon vegetate and arable cultivation will not be possible any more. Steep slopes are characteristic in the Börzsöny Mountains, roughly $40 \%$ of the area has slopes steeper than $17 \%$.

The different land use structure (figure 4) of the sites can be explained by different parent materials and relief conditions. In the Börzsöny the largest homogenous areas are covered by forest and they are in the highest slope gradient class. In the Zselic Hills the steepest slopes have a very low territorial extension; they are covered by forest but they are fragmented.

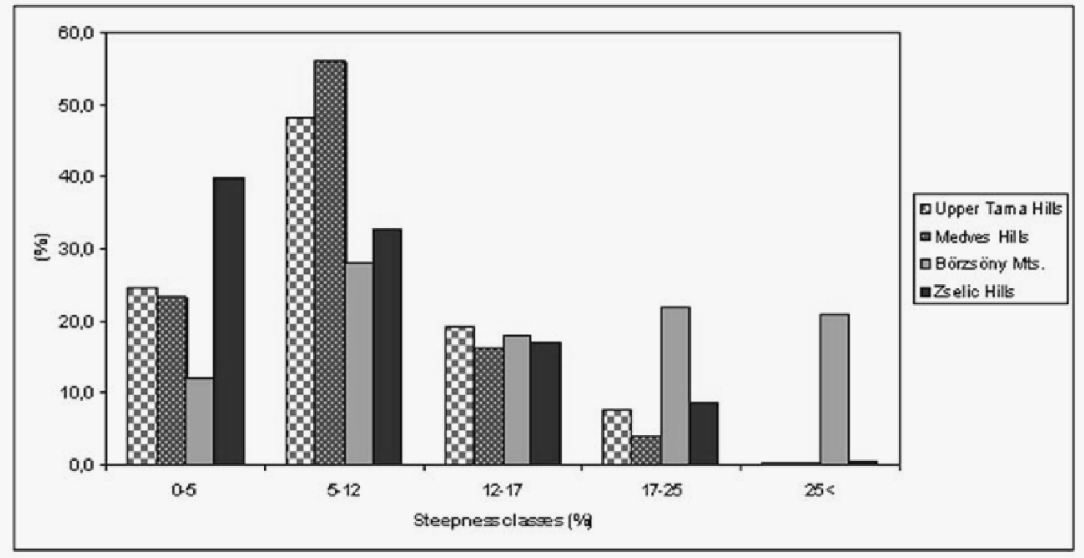

Figure 4: Land use distribution of the pilot areas derived form the CLC50 (2000) database.

There is an interesting relationship between gully erosion and land use. In all the pilot areas the surveyed gullies were in the forest when the map was prepared. If gullies are deeply incised arable cultivation must be stopped and these gullies will not be classified into arable land any more (Jakab [7]). Gullies will soon be covered by forest.

The overwhelming area of the Börzsöny is covered by forest, but the proportion of gullies outside the forest area is higher than in the forest. In the Zselic most of the gullies are in the forest $(90 \%)$ in spite of the fact that the percentage of forests is less. The same is true for the Medves and Tarna microregions where $85 \%$ and $90 \%$ of the gullies are in the forest. Intensive land use increases the rate of both sheet and gully erosion (Gábris et al. [16]).

\section{Conclusions}

The country wide cadastre of gullies identified the areas endangered by gully erosion. They include the hilly countries of Hungary covered by unconsolidated sediments as well as some mountainous. Gully erosion risk is present on various landscapes mainly because of the environmental conditions. 
The results obtained from the pilot areas point to various aspects of gully development. It is difficult to assess the role of the environmental factors because they are interrelated, they constitute a complex system and this system controls gully development. Previous studies (Jakab et al. [15]) revealed that that soil properties have the smallest effect on gully development.

Gullies determine the development and material flux of the landscape. As an already existing gully will remain in the landscape for a long time, medium and long term land use planning should ensure a minimum risk of gully erosion with special emphasis on afforestation.

\section{Acknowledgements}

Research activities reported in this paper were funded by the Hungarian Scientific Research Fund (OTKA K 76434) and the support is gratefully acknowledged here. The data input was carried out by Varga E. and this activity is also gratefully acknowledged by the authors.

\section{References}

[1] Prosser, I.P., Abernethy, B., Increased erosion hazard resulting from logrow construction during conversion to plantation forest. Forest Ecology and Management 123, pp. 145-155, 1999.

[2] Vandekerckhove, L., Muys, B., Poesen, J., de Weerdt, B., Coppe, N., A method for dendrochronological assessment of medium-term gully erosion rates. Catena 45, pp. 123-161, 2001.

[3] Gyssels, G., Poesen, J., Nachtergaele, J., Govers, G., The impact of sowing density of small grains on rill and ephemeral gully erosion in concentrated flow zones. Soil \& Tillage Research 64, pp. 189-201, 2002.

[4] Nachtergaele, J., Poesen, J., Steegen, A., Takken, I., Beuselinck, L., Vandekerckhove, L., Govers, G., The value of a physically based model versus an empirical approach ind the prediction of ephemeral gully erosion for loess-derived soils. Geomorphology 40, pp. 237-252, 2001.

[5] Vandekerckhove, L., Poesen, J., Oostwoud Wijdenes, D., Gyssels, G., Short-term bank gully retreat rates in Mediterranean environments. Catena 44, pp. 133-161, 2001.

[6] Poesen, J., Nachtergaelea, J., Verstraetena, G., Valentin, C., Gully erosion and environmental change: importance and research needs. Catena 50, pp. 91-133, 2003.

[7] Jakab, G., Gully types and possibilities of their investigation. Tájökológiai Lapok 4(1), pp. 17-33, 2006.

[8] Poesen, J., Vandaele, K., van Wesemael, B., Contribution of gully erosion to sediment production in cultivated lands and rangelands. IAHS Publications 236, pp. 251-266, 1996.

[9] Stefanovits, P., Várallyay, Gy., State and management of soil erosion in Hungary. Proceedings of the Soil Erosion and Remediation Workshop, US - Central and Eastern European Agro-Environmental Program. 27 April 27 - 1 May 1992, Budapest, Hungary, pp. 79-95, 1992. 
[10] Stefanovits, P., Duck, T., Soil Erosion in Hungary, OMMI: Budapest, Hungary, 1964.

[11] Kerényi, A., Soil erosion. Mapping, laboratory and field experiments, Akadémiai Kiadó: Budapest, Hungary, 1991.

[12] Kertész, Á., The Role Deep-cut Tracks in Linear Erosion. Geographical Essays in Hungary, MTA FKI: Budapest, Hungary, pp. 47-56, 1984.

[13] Kerényi, A., Kocsisné Hodosi, E., Quantitative study of forms and processes on loes in vineyards. Hungarian Geographical Bulletin 39 (1-4), pp. 29-54, 1990.

[14] Tóth, A., Szalai, Z., Tájökológia és tájtipológiai vizsgálatok a Tetves-patak vízgyüjtőjén. Tájökológiai Lapok 5, pp. 131-142, 2007.

[15] Jakab, G., Kertész, Á., Papp, S., Gully erosion in the Tetves catchment). Hungarian Geographical Bulletin 54(1-2), pp. 149-165, 2005.

[16] Gábris, Gy., Kertész, Á., Zámbó, L., Land use change and gully formation over the last 200 years in a hilly catchment. Catena 50, pp. 151-164, 2003.

[17] Rissac, 1991, http://www.mta-taki.hu/hu/osztalyok/gis-labor/agrotopo

[18] Büttner, G., Feranec, J., Jaffrain, G., Corine land cover update 2000, European Environment Agency, Copenhagen, Denmark, 2002.

[19] Rabus, B., Eineder, M., Roth, A., Bamler, R., The shuttle radar topography mission- a new class of digital elevation models acquired by spaceborne radar. Photogramm. Rem. Sens. 57, pp. 241-262, 2003.

[20] Madarász, B., Jakab, G., Volcanic soils of the High Börzsöny and their relationship with geomorphological conditions. Hungarian Geographical Bulletin 58(4), pp. 227-242, 2009.

[21] Dövényi, Z., (ed.). Magyarország kistájainak katasztere, MTA FKI: Budapest, 2010. 